\title{
Nondegradation of Fecal Cholesterol
}

\author{
in Subjects at High Risk \\ for Cancer of the Large Intestine
}

\author{
M. Lipkin, B. S. RedDy, J. Weisburger, and L. SCHEChter, Memorial \\ Sloan-Kettering Cancer Center, New York 10021, and American Health \\ Foundation, Valhalla, New York 10595
}

\begin{abstract}
A B S T R A C T In previous studies subjects with familial polyposis, the autosomal dominant disease leading to colon cancer, excreted higher levels of fecal cholesterol than normal subjects, with decreased conversion to degradation products. Findings suggested fecal cholesterol degradation as a marker of hereditary predisposition to colon cancer. Current measurements now have shown that affected individuals and asymptomatic progeny in a second population group with inherited predisposition to colon cancer are low converters of fecal cholesterol. The latter group consisted of highly colon cancer prone families without polyposis, in which patterns of inheritance similar to the autosomal dominant pattern of familial polyposis were observed. 24-h stool collections were obtained from 72 subjects who consumed mixed western diets. Mean percent degradation of fecal cholesterol to coprostanol, coprostanone, cholestanol, and cholestanone revealed significant decreases in fecal cholesterol conversion in affected and asymptomatic subjects in colon cancer prone families without polyposis $(P<0.001)$ compared to controls. This is in addition to those with familial polyposis $(P<0.001)$, and extends this marker of colon cancer susceptibility to a second population group with hereditary predisposition to colonic neoplasia.
\end{abstract}

Address reprint requests to Dr. Lipkin, Memorial SloanKettering Cancer Center.

Received for publication 18 September 1980 and in revised form 3 November 1980.

\section{INTRODUCTION}

Subjects with the dominant inherited disease, familial polyposis coli, excrete higher levels of fecal cholesterol than normal subjects, and show decreased conversion of fecal cholesterol to its degradation products (1-3). We now have extended these observations to a second population group at high risk for colon cancer, i.e., strongly colon cancer prone families in which individuals do not develop polyposis, and where the pattern of cancer inheritance resembles the autosomal dominant pattern of familial polyposis $(4,5)$. In this second group, affected individuals and a high fraction of asymptomatic progeny also had significantly increased levels of fecal cholesterol with low cholesterol conversion. This was in contrast to control subjects in the general population.

\section{METHODS}

Three groups of volunteers from the New York metropolitan area were studied.

Group 1. 23 volunteers in 10 familial polyposis (FP) families, 9 volunteers had symptomatic polyposis of the colon $\left(\mathrm{FP}_{\mathrm{s}}\right)$ and 14 volunteers were asymptomatic and at risk for developing the disease $\left(\mathrm{FP}_{\mathrm{a}}\right)$.

Group 2. 18 volunteers from 6 familial colon cancer (FCC) families without polyposis, 5 subjects were symptomatic since they had a colon cancer followed by a curative segmental

'Abbreviations used in this paper: FCC, familial colon cancer; FP, familial polyposis. 
resection of the affected portion of the colon $\left(\mathrm{FCC}_{\mathrm{s}}\right) ; 13$ volunteers were asymptomatic and at risk for the development of colon cancer $\left(\mathrm{FCC}_{\mathrm{a}}\right)$.

Group 3. 15 spouse controls and 16 volunteers from the general population.

Examples of pedigrees in the FCC group are shown in Fig. 1. All subjects had been examined with colonoscopy, to verify the presence of polyposis in the $\mathrm{FP}_{\mathrm{s}}$ group, and to verify the absence of polyps and colon cancer in the other groups. All subjects were consuming a mixed western diet, and had not received antibiotics for $4 \mathrm{wk}$ before the measurements. Individual 24-h stool samples were collected and analyzed in duplicate for cholesterol and its microbial metabolites, using thin layer chromatographic and gas liquid chromatographic methods as described (6).

\section{RESULTS}

Table I shows levels of fecal neutral sterols and degradation products in the three groups. In controls, the mean level of fecal cholesterol was $3.2 \pm 0.50 \mathrm{mg} / \mathrm{g}$ SE dry feces; the mean percent cholesterol degradation to coprostanol, coprostanone, cholestanol, and

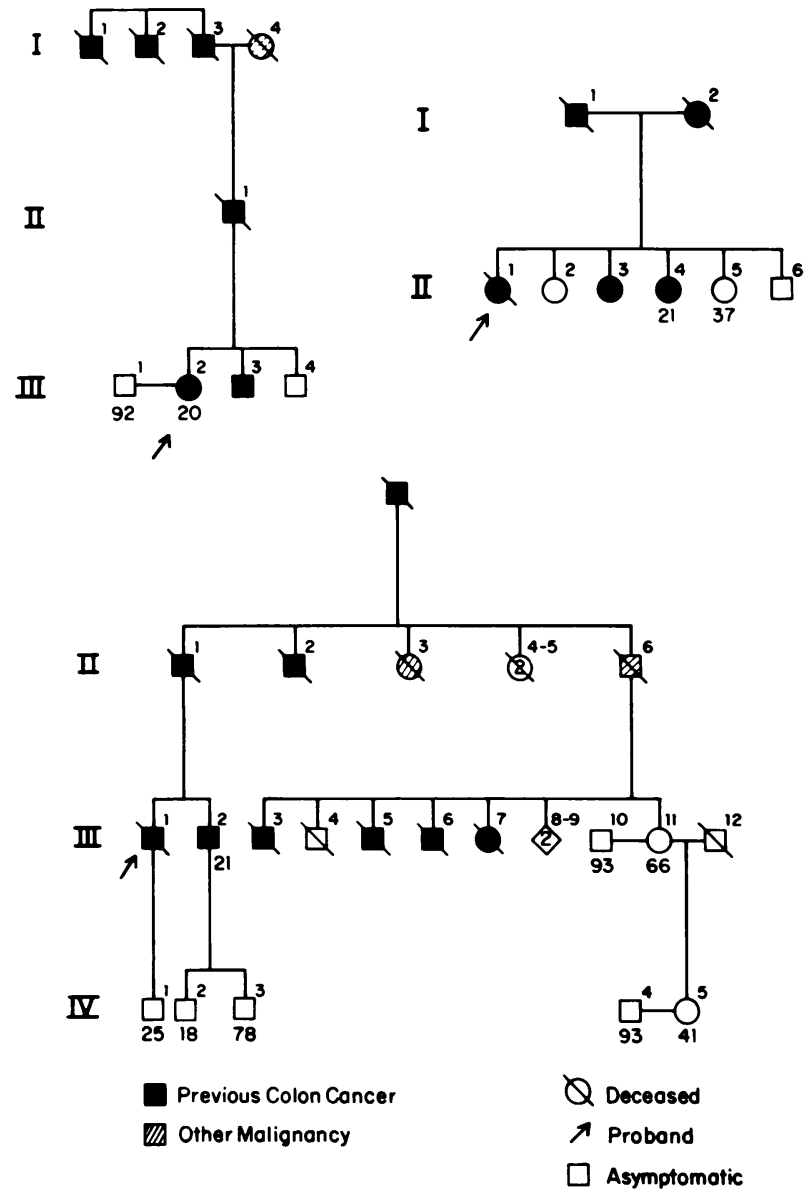

FIGURE 1 Representative FCC pedigrees with percent degradation of cholesterol indicated below symbol for each subject studied. cholestanone was $85 \pm 2 \%$ SE. A tentative normal lower limit of fecal cholesterol degradation, derived from the mean value in the control group minus $2 \mathrm{SD}$, was $60 \%$.

In the $\mathrm{FP}_{\mathrm{s}}$ group, most individuals had cholesterol degradation $<60 \%$, and in one volunteer the percent degradation was $69 \%$. The mean level of fecal cholesterol was $13.3 \pm 1.7 \mathrm{mg} / \mathrm{g}$ dry feces, and mean cholesterol degradation for the group was $20 \pm 8 \%$. Five $\mathrm{FP}_{\mathrm{a}}$ volunteers had low cholesterol conversion; mean level of fecal cholesterol in the subgroup of low converters was $12.9 \pm 2.8 \mathrm{mg} / \mathrm{g}$ dry feces, and mean cholesterol degradation was $11 \pm 6 \%$; nine volunteers were high converters with mean fecal cholesterol of $1.6 \pm 0.2$ $\mathrm{mg} / \mathrm{g}$ dry feces and mean cholesterol degradation of $90 \pm 3 \%$.

In the $\mathrm{FCC}_{\mathrm{s}}$ group, all volunteers previously affected with colon cancer had cholesterol degradation below the normal range, with mean fecal cholesterol $16.4 \pm 2.0$ $\mathrm{mg} / \mathrm{g}$ dry feces, and mean percent degradation of $33 \pm 8 \%$. Nine of the $\mathrm{FCC}_{\mathrm{a}}$ volunteers were low cholesterol converters with mean fecal cholesterol $15.3 \pm 1.9$ $\mathrm{mg} / \mathrm{g}$ dry feces and mean percent cholesterol degradation of $25 \pm 6 \%$. Four of the FCC $_{a}$ volunteers were high fecal cholesterol converters with mean cholesterol of $3.9 \pm 1.9 \mathrm{mg} / \mathrm{g}$ and mean percent degradation of $82 \pm 7 \%$. Although these individuals did not have adenomatous polyposis, single adenomas were found in one volunteer in each of the $\mathrm{FCC}_{\mathrm{s}}$ and $\mathrm{FCC}_{\mathrm{a}}$ groups; a relationship between endoscopically visible adenomas and cholesterol-conversion rate was not apparent.

\section{DISCUSSION}

The only well-defined population group at increased risk for cancer of the large intestine previously characterized by low fecal degradation of cholesterol, are individuals affected with familial polyposis (1-3). Our findings have now extended this observation to a second high risk population group, namely affected individuals and asymptomatic progeny in highly colon cancer prone families who do not have polyposis; a high fraction of these volunteers have now been found with high levels of fecal cholesterol with little conversion to cholesterol degradation products.

Familial aggregates in the FCC group are at high risk for cancer of the large intestine, and often are characterized by an extensive pattern of inheritance resembling the autosomal dominant pattern found in familial polyposis $(4,5)$. These families have a higher incidence of colon cancer and generally earlier age of onset, than reported in other series (7) where familial associations have been noted. Individuals in the FCC group, and individuals in the general population who have first and second degree relatives with colon cancer, are found with higher frequency than are individuals with familial polyposis coli $(7,8)$. 
TABLE I

Fecal Neutral Sterols in Subjects at High Risk for Cancer of the Large Intestine and Controls Consuming a Mixed Western Diet

\begin{tabular}{|c|c|c|c|c|c|c|c|c|c|c|}
\hline \multirow[b]{2}{*}{ Population group } & \multirow{2}{*}{$\begin{array}{l}\text { No. of } \\
\text { indi- } \\
\text { viduals }\end{array}$} & \multirow{2}{*}{$\begin{array}{c}\text { Age } \\
\text { range }\end{array}$} & \multicolumn{2}{|c|}{ Sex } & \multirow[b]{2}{*}{ Cholesterol } & \multicolumn{4}{|c|}{ Fecal cholesterol degradation products } & \multirow{2}{*}{$\begin{array}{l}\text { \% Degra- } \\
\text { dation }\end{array}$} \\
\hline & & & $\mathbf{M}$ & $\mathbf{F}$ & & Coprostanol & Coprostanone & Cholestanol & Cholestanone & \\
\hline & & & & & mg/g dry feces & & \multicolumn{2}{|c|}{ mg/g dry feces } & & \\
\hline \multicolumn{11}{|l|}{ FP } \\
\hline $\begin{array}{l}\text { Symptomatic } \\
\text { At risk }\end{array}$ & 9 & $12-51$ & 5 & 4 & $13.3 \pm 1.7$ & $2.57 \pm 1.3$ & $0.84 \pm 0.43$ & $0.39 \pm 0.24$ & $0.18 \pm 0.13$ & $20 \pm 8^{*}$ \\
\hline $\begin{array}{c}\text { Low con- } \\
\text { verters }\end{array}$ & 5 & $17-46$ & 3 & 2 & $12.9 \pm 2.8$ & $1.22 \pm 0.65$ & $0.10 \pm 0.04$ & $0.23 \pm 0.08$ & 0.0 & $11 \pm 6^{*}$ \\
\hline $\begin{array}{c}\text { High con- } \\
\text { verters }\end{array}$ & 9 & $12-23$ & 5 & 4 & $1.6 \pm 0.2$ & $16.9 \pm 4.3$ & $3.09 \pm 0.70$ & $1.48 \pm 0.17$ & 0.0 & $90 \pm 3$ \\
\hline \multicolumn{11}{|l|}{ FCC } \\
\hline $\begin{array}{l}\text { Symptomatic } \\
\text { At risk }\end{array}$ & 5 & $31-59$ & 1 & 4 & $16.4 \pm 2.0$ & $5.30 \pm 2.0$ & $0.75 \pm 0.21$ & $0.81 \pm 0.19$ & $0.58 \pm 0.50$ & $33 \pm 8^{*}$ \\
\hline $\begin{array}{c}\text { Low con- } \\
\text { verters }\end{array}$ & 9 & $7-43$ & 2 & 7 & $15.3 \pm 1.9$ & $4.60 \pm 1.2$ & $0.32 \pm 0.11$ & $0.52 \pm 0.14$ & $0.17 \pm 0.12$ & $25 \pm 6^{*}$ \\
\hline $\begin{array}{c}\text { High con- } \\
\text { verters }\end{array}$ & 4 & $23-59$ & 1 & 3 & $3.9 \pm 1.9$ & $12.1 \pm 1.2$ & $2.03 \pm 0.61$ & $0.97 \pm 0.27$ & $0.85 \pm 0.8$ & $82 \pm 7$ \\
\hline Controls & 31 & $10-62$ & 17 & 14 & $3.2 \pm 0.50$ & $14.9 \pm 1.2$ & $2.39 \pm 0.33$ & $2.81 \pm 1.5$ & $0.034 \pm 0.02$ & $85 \pm 2$ \\
\hline
\end{tabular}

Average values $( \pm \mathrm{SE})$ of cholesterol and degradation products in each population group are shown. In the last column for each population group, the average percent degradation is shown where a given patient's percent degradation is defined as degradation products divided by total neutral sterols $\times 100$.

* Percent degradation of cholesterol in the group differs significantly from the controls $(P<0.001)$ with the Student's $t$ test. A tentative lower limit of $60 \%$ for degradation of cholesterol in the control group has been derived from the mean value minus two standard deviations. Low converters have been defined as having percent degradation $<60 \%$ and high converters having values $>60 \%$.

Factors leading to decreased conversion of cholesterol in fecal specimens of these colon cancer prone subjects have not been elucidated. Possibilities that have been considered include the microbial degradation of cholesterol which could differ in the two groups $(9,10)$ and the metabolism of cholesterol in intestinal cells which might be modified in these individuals with hereditary predisposition to colon cancer.

Wilkins and Hackman (10) have shown that two patterns of neutral steroid conversion exist in subjects in the general population; a larger population group is characterized by extensive conversion of cholesterol to its degradation products, and a minor group is characterized by little or no fecal conversion of cholesterol. These patterns were generally found to be stable over long periods of time, and the possibility that differences in risk level for colon cancer might be associated with cholesterol excretion has been considered $(10,11)$.

Previous studies also have indicated that fecal cholesterol conversion patterns were equally distributed between males and females, were independent of age (10), and increased after ileoproctostomy (2); conversion rate was not directly related to fecal transit time (10). Although dietary factors have been shown capable of modifying fecal cholesterol excretion (12-15), diets were generally comparable in studies that identified high and low converter groups (10). Fecal conversion patterns similar to those observed for cholesterol also have been noted for the plant steroids, sitosterol and campesterol (10). Of further interest is the report that infants $<1$ yr of age convert little or no cholesterol to coprostanol (16).

In attempts to improve the surveillance of individuals at high risk for cancer of the large intestine, it is important to develop indices that will identify these subjects before they develop advanced disease. The observation of excess cholesterol in fecal contents of individuals with inherited predisposition to colon cancer suggests a new means of surveillance of these subjects, and points to possible relationships between cholesterol metabolites and mechanisms of colon carcinogenesis. Studies are now under way to develop both of these areas further.

\section{ACKNOWLEDGMENTS}

This work was aided by contract CP-43366, grant CA-08748, and National Large Bowel Cancer Project grant CA-16382, awarded by the National Cancer Institute, Departments of Health, Education, and Welfare. We wish to acknowledge the technical assistance of Ms. Laurel Mathews, Ms. Barbara Simi, and Ms. Loretta Darby. 


\section{REFERENCES}

1. Drasar, B. S., M. F. Bone, M. J. Hill, and C. G. Marks. 1975. Colon cancer and bacterial metabolism in familial polyposis. Gut. 16: 824.

2. Watne, A. L., H-Y. Lai, T. Mance, and S. Core. 1976. Fecal steroids and bacterial flora in patients with polyposis coli. Am. J. Surg. 131: 42-46.

3. Reddy, B. S., A. Mastromarino, C. Gustafson, M. Lipkin, and E. L. Wynder. 1976. Fecal bile acids and neutral sterols in patients with familial polyposis. Cancer(Phila.). 38: $1694-1698$.

4. Lynch, H. T., R. E. Harris, W. A. Bardawil, P. M. Lynch, H. A. Guirgis, M. J. Swartz, and J. F. Lynch. 1977. Management of hereditary site-specific colon cancer. Arch. Surg. 112: 170-174.

5. Fraumeni, J. F., Jr. 1977. Clinical patterns of familial cancer. In Genetics of Human Cancer. J. J. Mulvihill, R. W. Miller, and J. Fraumeni, editors. Raven Press, New York. 223-233.

6. Reddy, B. S., A. R. Hedges, K. Laakso, E. L. Wynder. 1978. Metabolic epidemiology of large bowel cancer. Cancer (Phila.) 42: 2832-2838.

7. Lovett, E. 1976. Family studies in cancer of the colon and rectum. Br. J. Surg. 63: 13-18.

8. Macklin, M. 1960. Inheritance of cancer of the stomach and large intestine in man. J. Natl. Cancer Inst. 24: $551-571$
9. Sadzikowski, M. R., J. F. Sperry, and T. D. Wilkins. 1977. Cholesterol-reducing bacterium from human feces. Appl. Environ. Microbiol. 34: 355-362.

10. Wilkins, T. D., and A. S. Hackman. 1974. Two patterns of neutral steroid conversion in the feces of normal north Americans. Cancer Res. 34: 2250-2254.

11. Cruse, P., M. Lewin, and C. G. Clark. 1979. Dietary cholesterol is co-carcinogenic for human colon cancer. Lancet. I: 752-755.

12. Eneroth, P., K. Hellstrom, and R. J. Ryhage. 1964. Identification and quantification of neutral fecal steroids by gas-liquid chromatography and mass spectrometry. $J$. Lipid Res. 5: 245-262.

13. Connor, W. E., D. T. Witiak, D. B. Stone, and M. L. Armstrong. 1969. Cholesterol balance and fecal neutral steroid and bile acid excretion in normal men fed dietary fats of different fatty acid composition. J. Clin. Invest. 48: 1363-1375.

14. Crowther, J. S., B. S. Drasar, P. Goddard, M. J. Hill, and K. Johnson. 1973. The effect of chemically defined diets on the faecal flora and faecal steroid concentration. Gut. 14: 790-793.

15. DenBesten, L., R. H. Reyna, W. E. Connor, and L. D. Stegink. 1973. The different effects on the serum lipids and fecal steroids of high carbohydrate diets given orally or intravenously. J. Clin. Invest. 52: 1384-1393.

16. Gustafsson, J. A., and B. Werner. 1968. Fecal sterols in infants. Acta Physiol. Scand. 73: 305-310. 